\title{
Sistem Penjualan Berbasis E-Commerce Menggunakan Metode Objek Oriented pada Distro Dlapak Street Wear
}

\author{
Diki Susandi ${ }^{1}$, Sukisno ${ }^{2}$ \\ ${ }^{I}$ Program Studi Sistem Informasi Fakultas Teknologi Informasi Universitas Serang Raya \\ Jln. Raya Cilegon Serang KM. 5 - Taman Drangong Kota Serang \\ unsera.diky@gmail.com \\ ${ }^{2}$ Program Studi Teknik Informatika - Universitas Islam Syekh Yusuf \\ Jln. Maulana Yusuf - Babakan Kota Tangerang \\ ${ }^{2}$ sukisnonhp@gmail.com
}

\begin{abstract}
Abstrak - Berawal dari adanya masalah pada pemasaran Distro Dlapak Street Wear yang tidak maksimum, tidak ada media yang membantu memudahkan pelanggan dari luar kota untuk transaksi, dan tidak ada yang dapat membantu dalam memasarkan produk perangkat komputer untuk memasarkan produknya setiap hari maka dikembangkan suatu aplikasi penjualan online pada Distro Dlapak Street Wear. Penjualan online atau e-commerce adalah suatu aplikasi dan proses bisnis yang menghubungkan toko dan konsumen melalui transaksi elektronik dan dapat membantu pihak toko dalam pemasaran produk yang maksimal. Maka diwujudkan sebuah aplikasi dengan melakukan penelitian yang bertujuan membantu Distro Dlapak Street Wear dalam memperluas cakupan promosi, membantu pelanggan yang berasal dari luar kota agar tetap dapat berbelanja dan memaksimalkan dalam pemasaran produk. Penelitian pengembangan sistem yang dilakukan merupakan jenis Penelitian Terapan (Applied Research). Dalam penelitian ini akan menerapkan teori analisis sistem dengan pendekatan berorientasi obyek. Pengujian dilakukan dengan metode ISO 9126. Hasil penelitian dapat langsung diterapkan untuk memecahkan permasalahan pada Distro Dlapak Street Wear.
\end{abstract}

Kata Kunci - Penjualan Online, E-Commerce, Transaksi Elektronik, Orientasi Obyek, ISO 9126.

\section{PENDAHULUAN}

Dengan kemajuan teknologi yang sangat cepat khususnya di bidang komputer dan internet, hal tersebut sangat efektif untuk menciptakan sebuah karya. Komputer yang berperan sebagai media pengolahan data sangat penting dalam menyelesaikan pekerjaan. Selain itu komputer juga dapat digunakan untuk media komunikasi, yaitu dengan menggunakan fasilitas internet. Manfaat internet juga dapat memperluas wawasan ataupun menambah teman. Selain itu mereka juga dapat mencari informasi-informasi yang aktual ataupun melakukan transaksi secara online. Teknologi komputer juga digunakan untuk penjualan, salah satu fasilitas internet untuk melakukan penjualan online yang dikenal dengan istilah e-commerce.

Distro Dlapak Street Wear ini bergerak di bidang penjualan pakaian dan aksesoris. Distro ini sekarang masih memakai sistem manual. Media promosi yang di pakai saat ini masih menggunakan selebaran-selebaran, iklan di koran, memasang baleho sehingga membutuhkan biaya yang cukup mahal. Cara tersebut dirasakan kurang efektif. Jadi diperlukan sebuah solusi atas permasalahan yang ada dengan merancang website sistem informasi pemesanan produk yang bertujuan untuk membantu memperlancar proses penjualan yang dilakukan. Berdasarkan uraian di atas, maka dilakukan penelitian untuk menciptakan sebuah prototype sistem penjualan berbasis e-commerce yang dapat membantu memperlancar proses penjualan tersebut.

\section{METODOLOGI PENELITIAN}

A. Metode Penelitian

Penelitian Pengembangan Sistem yang dilakukan merupakan jenis Penelitian Terapan (Applied Research). Hasil penelitian dapat langsung diterapkan untuk memecahkan permasalahan yang dihadapi. Dalam penelitian ini akan menerapkan teori analisis sistem dengan pendekatan berorientasi obyek, implementasi hasil analisis dan perancangan menggunakan pemrograman Adobe Dreamweaver dan Database SQL Server, pengujian validasi menggunakan Focus Group Discussion, serta pengujian kualitas perangkat lunak yang dihasilkan dengan mengadopsi model ISO 9126.
B. Metode Pengumpulan Data
Metode pengumpulan data yang digunakan dalam penelitian ini adalah: 
1). Metode Wawancara. Wawancara dengan pihak-pihak yang berkaitan dengan penelitian. Teknik wawancara dilakukan dengan wawancara berstruktur. Dalam wawancara tersebut peneliti telah menyiapkan daftar pertanyaan yang berkaitan dengan prototipe. Pertanyaanpertanyaan untuk mendapatkan data yang terkait dengan sistem yang sedang berjalan saat ini.

2). Metode Observasi. Observasi atau pengamatan langsung terhadap profil organisasi dan obyek penelitian. Teknik observasi dilakukan dengan observasi berstruktur dengan menyiapkan daftar kebutuhan data dan sumber data. Proses observasi dilakukan untuk mempelajari, tujuan dan struktur organisasi, proses bisnis dan kebijakan sistem informasi yang telah ada di Distro.

3). Metode Studi Pustaka. Metode pengumpulan data yang diperoleh dengan mempelajari, meneliti, dan membaca buku, jurnal, skripsi, tesis yang berhubungan dengan pengembangan sistem.

C. Teknik Perancangan Sistem

Pada proses perancangan, teknik perancangan yang dilakukan adalah:

1). Perancangan struktur statis program atau spesifikasi sistem. Dimodelkan dengan Usecase Diagram dan Class Diagram.

2). Perancangan Physical Architecture untuk memodelkan distribusi aplikasi. Dimodelkan dengan Deployment Diagram.

3). Perancangan Antarmuka Pengguna. Meliputi Perancangan Navigasi, Form Input, dan Form Output.

4). Perancangan Database. Untuk memodelkan struktur data dan hubungan antar data. Dimodelkan dengan EntityRelationship Diagram.

5). Perancangan Infrastructure Architecture (Hardware, Software, dan Network).

D. Teknik Pengolahan Data

Data yang didapatkan dari hasil setiap instrumen kuesioner akan dihitung dimana skor persentase didapat dari:

$$
\% \text { skor }=\frac{\text { skoraktual }}{\text { skorideal }} \times 100 \%
$$

Setelah mendapatkan hasil berupa nilai kuantitatif dari perhitungan, kemudian nilai dikonversi menjadi nilai kualitatif berskala 5 dengan acuan skala likert seperti pada tabel II.

Tabel 1. Konversi Skala Likert

\begin{tabular}{|c|c|c|}
\hline No & $\%$ & Kriteria \\
\hline 1 & $0,00-20,00$ & Tidak Baik \\
\hline 2 & $20,01-52,00$ & Kurang Baik \\
\hline 3 & $52,01-68,00$ & Cukup Baik \\
\hline 4 & $68,01-84,00$ & Baik \\
\hline 5 & $84,01-100$ & Sangat Baik \\
\hline
\end{tabular}

\section{HASIL DAN PEMBAHASAN}

A. Analisis Desain Menggunakan Usecase Diagram

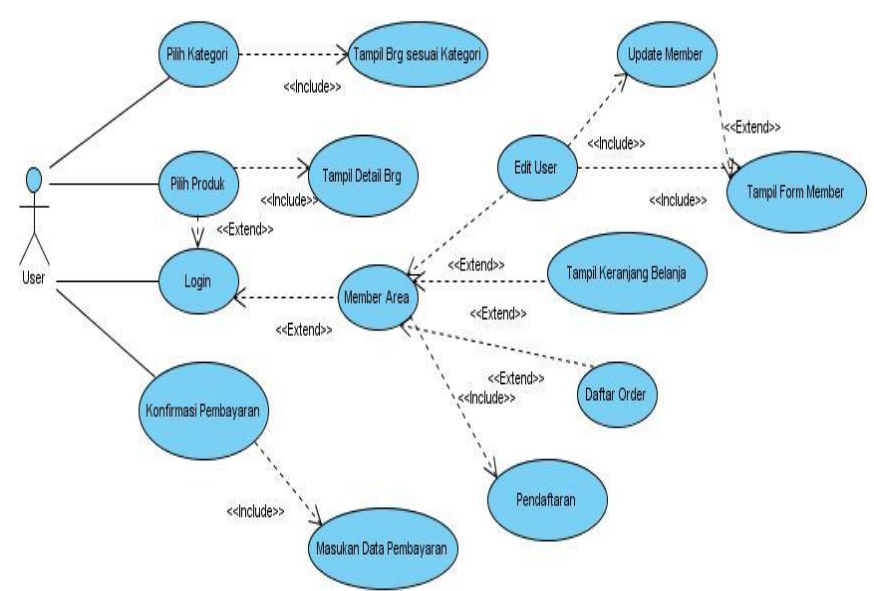

Gambar 1. Usecase Diagram Halaman Pelanggan

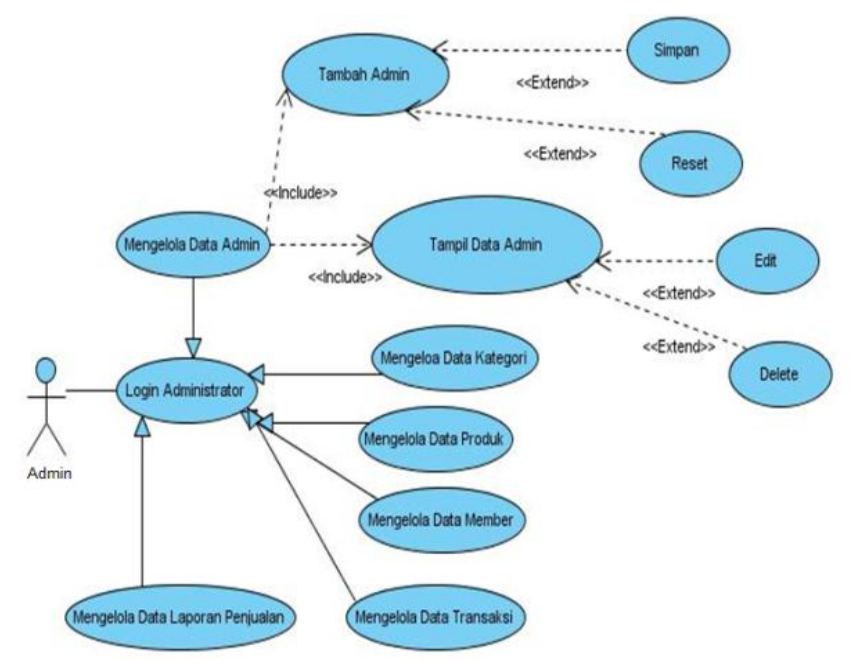

Gambar 2. Usecase Diagram Mengelola Data Admin

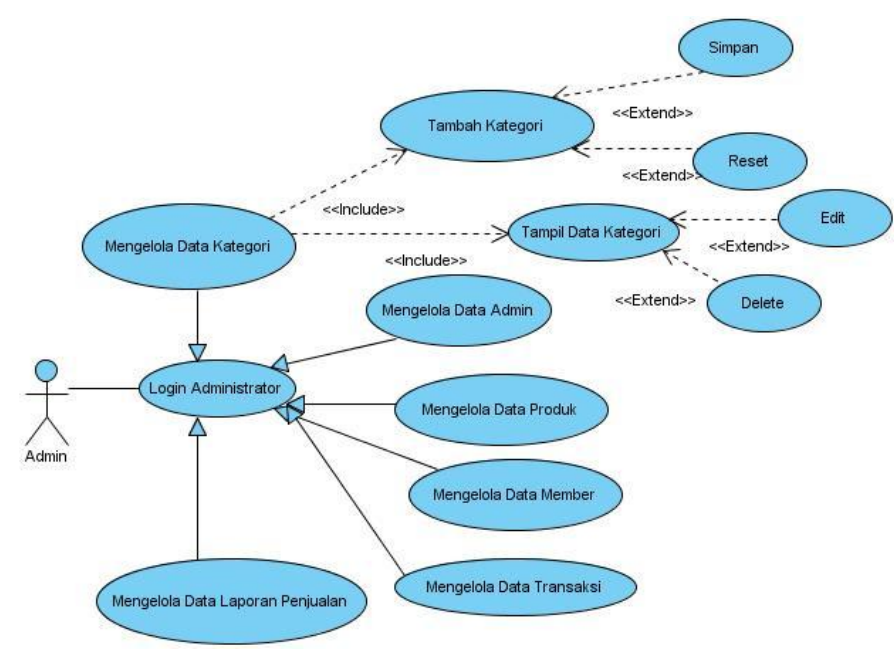

Gambar 3. Usecase Diagram Mengelola Data Kategori 


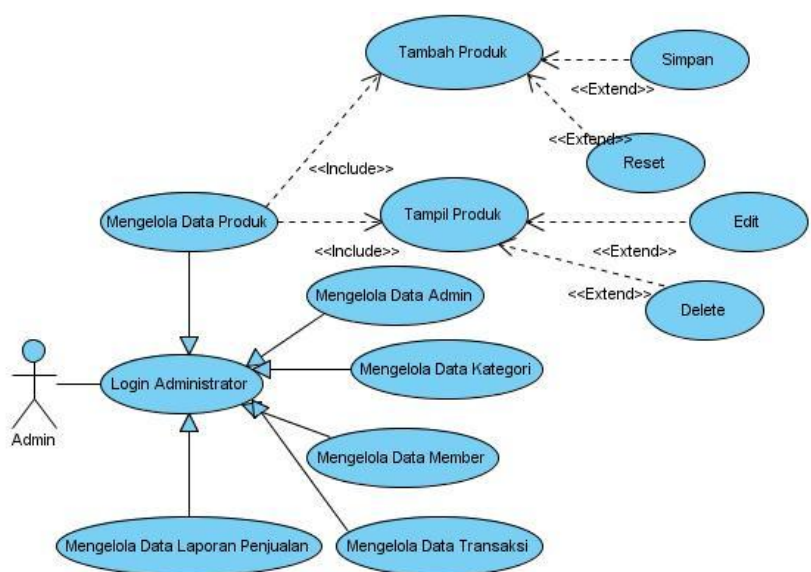

Gambar 4. Usecase Diagram Mengelola Data Produk

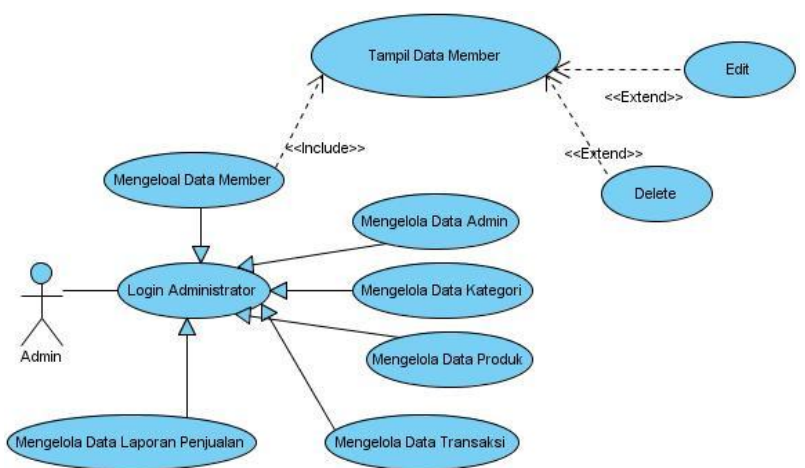

Gambar 5. Usecase Diagram Mengelola Data Member

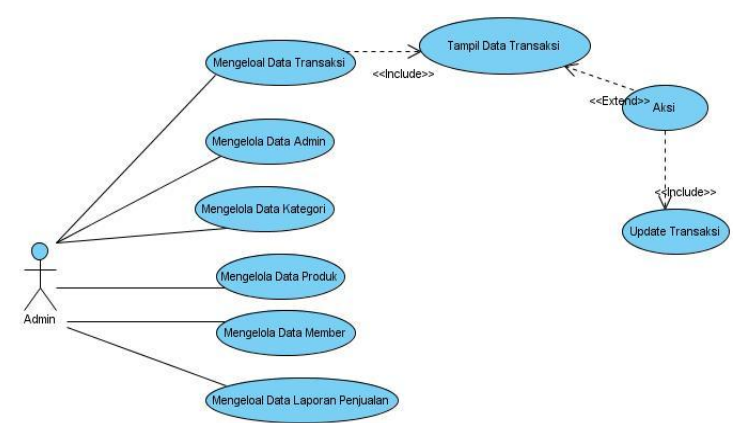

Gambar 6. Usecase Diagram Mengelola Data Transaksi

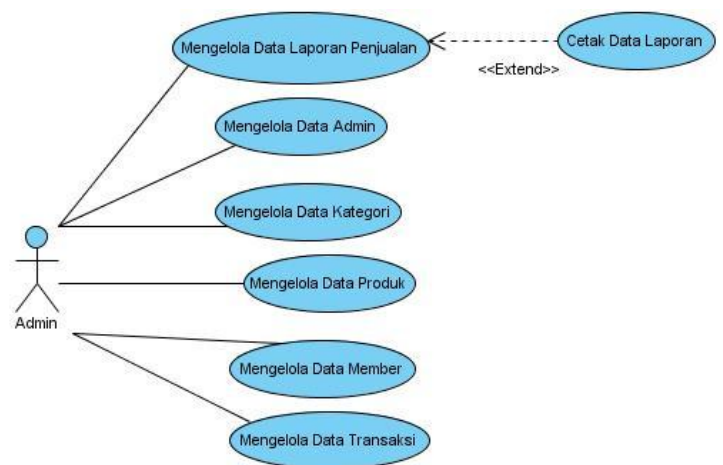

Gambar 7. Usecase Diagram Mengelola Data Laporan

\section{B. Entity Relationship Diagram}

Entitiy Relationship Diagram menjelaskan hubungan antar data dalam basis data yang terdiri dari object-object tersebut. Dalam ERD hubungan atau relasi dapat terdiri dari sejumlah entitas yang disebut dengan derajat relasi. ERD yang ada pada sistem ini sebagai berikut:

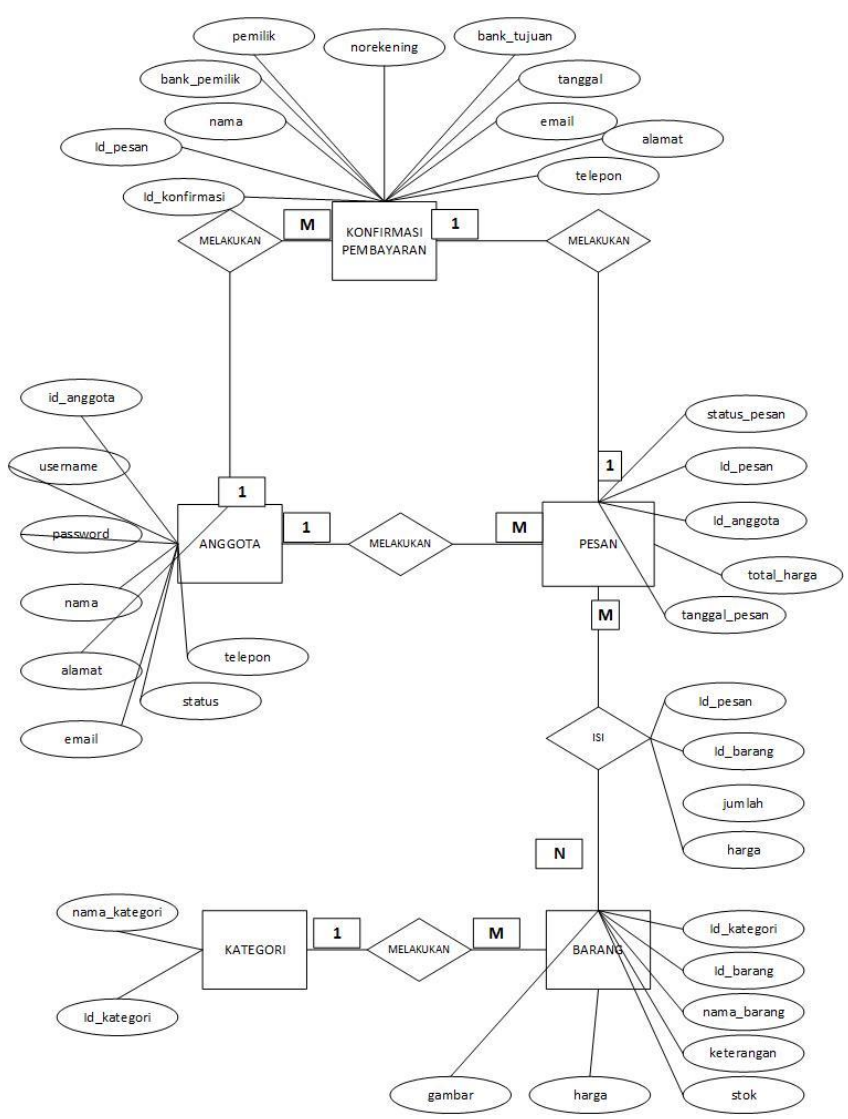

Gambar 8. Entity Relationship Diagram

C. User Interface

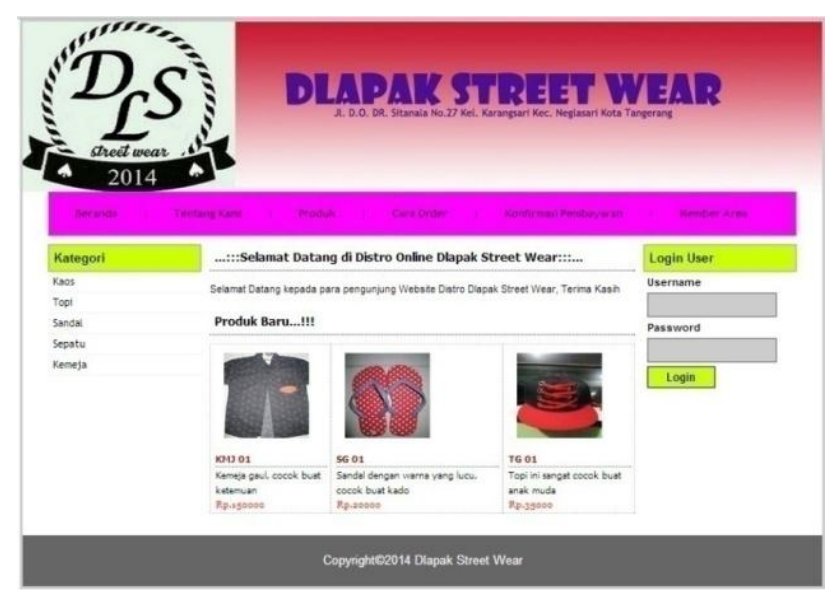

Gambar 9. Tampilan Halaman Utama 


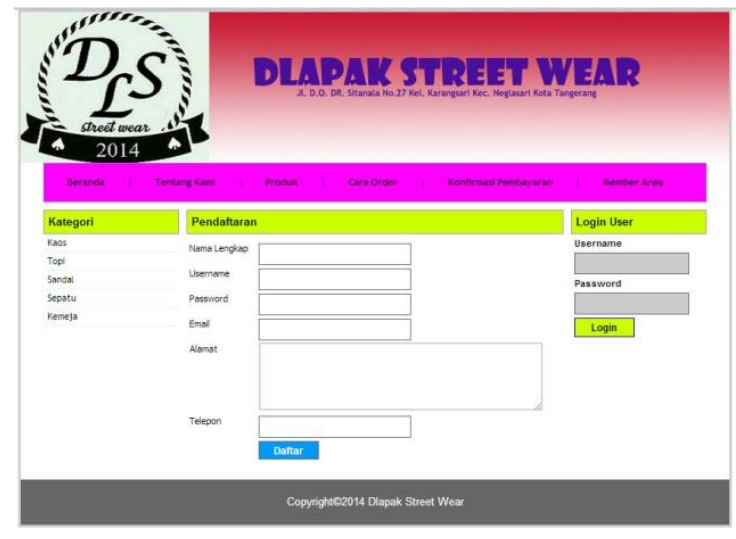

Gambar 10. Halaman Daftar Member

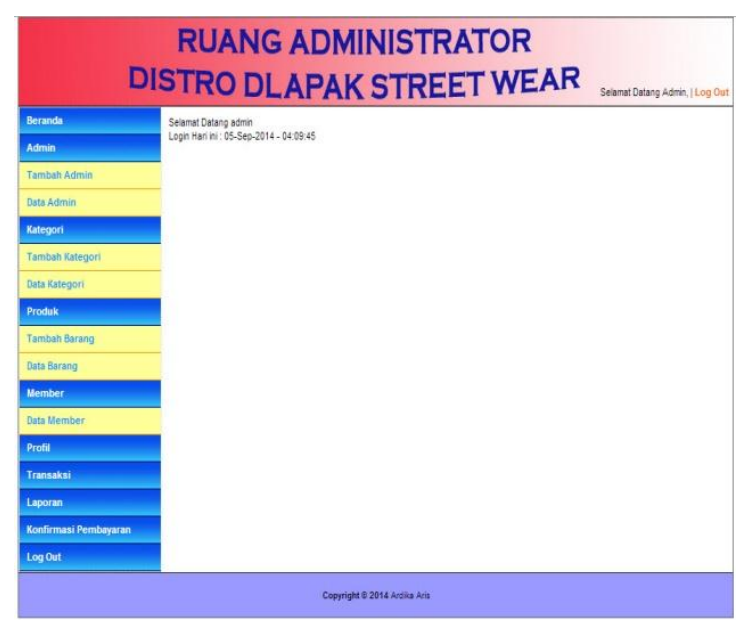

Gambar 11. Halaman Utama Admin

D. Pengujian Menggunakan ISO 9126

Berdasarkan analisis data yang diperoleh dari kuesioner, berikut rekapitulasi hasil pengujian kualitas berdasarkan empat aspek kualitas perangkat lunak menurut ISO 9126:

Tabel 2. Hasil ISO 9126

\begin{tabular}{|c|c|c|c|c|}
\hline Aspek & $\begin{array}{c}\text { Skor } \\
\text { Aktual }\end{array}$ & $\begin{array}{c}\text { Skor } \\
\text { Ideal }\end{array}$ & $\begin{array}{c}\text { \% Skor } \\
\text { Aktual }\end{array}$ & Kriteria \\
\hline Functionality & 249 & 270 & 92,23 & Sangat Baik \\
\hline Reliability & 137 & 150 & 91,34 & Sangat Baik \\
\hline
\end{tabular}

\begin{tabular}{|c|c|c|c|c|}
\hline Aspek & $\begin{array}{c}\text { Skor } \\
\text { Aktual }\end{array}$ & $\begin{array}{c}\text { Skor } \\
\text { Ideal }\end{array}$ & $\begin{array}{c}\text { \% Skor } \\
\text { Aktual }\end{array}$ & Kriteria \\
\hline Usability & 223 & 240 & 92,91 & Sangat Baik \\
\hline Efficiency & 79 & 90 & 87,78 & Sangat Baik \\
\hline Rata-Rata & 172 & 188 & 91,07 & Sangat Baik \\
\hline
\end{tabular}

Berdasarkan tabel di atas dapat disimpulkan bahwa tingkat kualitas perangkat lunak sistem informasi penjualan online secara keseluruhan dalam kriteria Sangat Baik, dengan persentase $91,07 \%$.

\section{KESIMPULAN}

Sistem Penjualan E-Commerce pada Distro Dlapak Street Wear ini merupakan prototipe aplikasi sistem komputerisasi yang dibuat dengan berbasis web dan memuat database pengolahan data informasi secara terpusat sehingga dapat mengelolah database tersebut menjadi sebuah informasi yang dibutuhkan oleh para pengguna.

Sistem Penjualan E-Commerce pada Distro Dlapak Street Wear ini memiliki beberapa keuntungan, diantaranya dapat diakses dari mana saja dan kapan saja melalui jaringan internet, serta peningkatan efisiensi dan efektifitas proses penyampaian informasi produk tanpa harus terhalang oleh waktu dan tempat.

Hasil pengujian menggunakan ISO 9126 didapatkan keseluruhan sistem berada dalam kriteria sangat baik dengan persentase $91,07 \%$.

\section{REFERENSI}

[1] Andi, Pengembangan Sistem Menggunakan Pendekatan Protoype, Gava Media, Yogyakarta, 2010.

[2] Farisi, Pajrin. 2011. Proyek Membuat Website Jejaring Sosial Dengan Joomla. Yogyakarta: Lokomedia.

[3] ISO/ IEC, Software engineering: product quality - part 2 - external metric, Canada: Int ernat ional t echnical report, 2001.

[4] Kusrini, Andri Koniyo. 2007. Tuntutan Praktis Membangu Sistem Informasi Akuntansi dengan Visual Basic dan Microsoft SQL Server. Yogyakarta: CV. ANDI OFFSET.

[5] Wong, Jony. 2010. Internet Marketing for Beginners. Jakarta: PT. Elex Media Komputindo. 